\title{
Implementation of English subject curriculum in Islamic secondary schools in Indonesia using Delphi method
}

\author{
Muhammad - Hasbullah - Syarifudin - Andi Anto Patak
}

DOI: 10.18355/XL.2019.12.04.12

\begin{abstract}
This study was aimed to investigate the implementation of English subject Curriculum used in Islamic secondary schools in Makassar city, South Sulawesi, Indonesia. Currently, English subject curriculum includes elements of English and characters as a new approach to replace the previous curriculum. The elements of English subject should be developed together with regional and national characters (values of cultures and beliefs). This study employed survey method and Delphi technique to collect the data. The survey method was used to analyze the elements of English and characters which were collected through eighty two curriculum developers and English teachers. Delphi technique was used to verify the results of the inclusion of elements of English and characters. It used meaningful communication with selected experts of English teachers and curriculum developers working in Islamic secondary schools. The experts answered a list of Delphi for two rounds and one another round was interviewed for final clarification. The findings confirmed that most respondents still had shortage experience to develop and implement this current English subject curriculum. The experts claimed that the practitioners in schools need to be trained to develop precise themes and topics and the ways to integrate the characters in the lesson plan and to evaluate the student's characters. Also, the practitioners in schools should make together the strategies to include characters for teaching English as recommended by the national education regulation. The conclusion concerned with this study, practitioners should know many cultures and characteristics of people in pluralism country as recommended by the curriculum.
\end{abstract}

Key words: characters, English subject curriculum, Islamic secondary school, Delphi method

\section{Introduction}

The English language was first decided to be a foreign language subject in each secondary school up to university since Indonesia derived its independence in 1945 (Hasbullah, Sidin, 2014; Musriadi, 2016; Suwarno, 2011). To improve the quality of education, government endeavors to reform the curriculum for schoolings. The educational department of Indonesia revises the English subject curriculum from time to time due to its inadequacies (Hasbullah,Sidin, 2014; Suwarno, 2011). Yaumi (2013a) argues that the revision of currently English subject curriculum in Indonesia can also be seen as a reaction to the development of the language at the international level.

The latest development is empowering the English teachers, curriculum developers, and principals of schools to develop the curriculum autonomously (Hlebowitsh, 2005; Kemendikbud, 2012; Musriadi, 2016; Myles, Trautman, Schelvan, 2004). Although they have been empowered to develop the English subject curriculum, that conceptualized curriculum, however, must comply with the regulations of national education of Indonesia and its standards (Departemen Pendidikan Nasional, 2007; Kemendikbud, 2012). This regulation of national education is used as foundations to guide the development of courses in Indonesia. Official regulations of education determine the development of curriculum must be based on the official philosophy of Indonesia. The newest issue in education for schooling in Indonesia now is the 
implementation of curriculum 2013 - character, then, its other name is National Curriculum. In which, the "curriculum 2013 - character" is defined as a set of plans for all subjects which include aspects of characters in setting the objectives, content and learning materials, methods, and evaluation of students' (Kemendikbud, 2012; Yaumi, 2013a, 2013b). This study aims to explore the implementation of the current national curriculum of English subject, which include characters based on local and national cultures in Islamic secondary schools in South Sulawesi province, Indonesia. The curriculum developers and English teachers conceptualized the proposed investigation. Dede (2005), Sukmadinata (1997), and Sanjaya (2012) asserted that the government should optimize the role of teachers and curriculum developers to practice subject curriculum in schools.

\section{Literature review \\ English subject curriculum in Indonesia}

Since 1945, which is the year of independence for Indonesia, the English subject curriculum had undergone several changes. The latest change of English subject curriculum is best understood as School-Based Curriculum or KTSP 2006 (Suwarno, 2011), and the newest one is the "curriculum 2013 - character named National Curriculum which emphasizes to include character's values (Kemendikbud, 2012; Yaumi, 2013b). The character values which can be included in English subject teaching program are national and local cultures, beliefs, tradition, attitude and behavior, social life, science, and technology, etc. which should be in line with school's vision and mission and regulation of national education goal (Kemendikbud, 2012). Normally, those amendments were logical consequences of a political issue, government system, social cultures, economic, science and technology changes in the living of state community (Sudin, 2014). The main components of the English subject curriculum are vocabulary, grammar, pronunciation, phrases, and four skills of communication namely listening, speaking, reading, and writing skills (Lee Odell, 2001). For this purpose, Richards (2005) asserts that curriculum plays a fundamental part in the teaching and learning of English subject as a foreign language, especially in the four skills of English language. More importantly, the curriculum must be relevant to the students' lives. As such the "curriculum - 2013 character" should be developed dynamically by the demands and changes that occur in society.

The English subject curriculum is a formal curriculum developed and implemented in each educational unit of Graduates Competency Standards (Tim Peneliti Depdiknas, 2007). The Graduates Competency Standards in English subject curriculum which is emphasized in each subject curriculum aims to improve intelligence, knowledge, personality, noble character, and the skills to live independently and continuing or further ongoing education. This Graduates Competency Standards pressures on the development of teaching materials which must be developed and implemented by practitioners in schools (Glatthorn, 2004; Klein, McLeod, 1990; Sudin, 2014; Susanto, 2007). The terms intelligence, knowledge, personality, noble character, and skills have particular meaning in English subject curriculum (Lee Odell, 2001). Practitioners and composers of the curriculum at schools must look at those terms to be used in English subject curriculum implementation. They should also adjust the objectives of terms with the level of learners (Sanjaya, 2012; Sudin, 2014; Sukmadinata, 1997; Tim Peneliti Depdiknas, 2007)

The curriculum of English subject claims that intelligence refers to students' ability to learn about, learn from, understand, and interact with one's environment (Richards, 2005). Knowledge is defined as a fluid mix of framed experience, contextual information, values, and expert insight that provides a framework for evaluating and incorporating new experiences and information. Hence, knowledge means the students are able to know the facts, information, and skills acquired through experience or education; theoretical or practical understanding of a subject (Glatthorn, 
2004; Susanto, 2007; Suwarno, 2011). In implementing English subject curriculum, the curriculum developers and English teachers have authority to decide educational goals based on their own schools perspective (Glatthorn, 2004). In other words, those practitioners have a responsibility in constructing and formulating proper goals, choosing and constructing right lesson materials according to needs, interest, and student's development phases. In addition, English teacher may use various methods and teaching media, and constructing learning programs and use different methods of evaluation (Sanjaya, 2012). The curriculum of English subject should be made and developed systematically and detail, which will help the teachers in its implementation (Lonigan, Farver, Phillips, Clancy-Menchetti, 2011; O'Bannon \& Judge, 2004; Silva,Brice, 2004). However, the quality of the curricula depends on people who are involved in its implementation.

There is a significant change in the current National Curriculum in including characters than the previous curriculum for teaching English subject at school. In this decade, the government offers a framework to practitioners in schools to develop the curriculum based on values of national and local character (Kemendikbud, 2012); and (Yaumi, 2013b). The government also introduces the concept of values and character in education in that curriculum (Kemendikbud, 2012). By 2012, the government made mandatory to teachers, and it is compulsory for schools to implement values and character in education. The values and characters in education focus on morality, social cultures, and nationality (Kemendikbud, 2012; Sanjaya, 2012). These changes influence the implementation of the curriculum of English language subject in schools now. Sudin (2014) encourages and emphasizes that this curriculum provide a large opportunity to all teachers to develop autonomously their teaching materials, methods, and evaluation, which are appropriate with the school environment and students' needs.

Regarding with the revise of curriculum, practitioners should conceptualize and use materials for teaching English subject based on the richness of surrounding cultures. Intansari (2013), Richards (2001), Sugirin, et al. (2011, Suwarno (2011) assert that English teacher can propose appropriate regional and national cultural materials for teaching English subject to the curriculum developers and principals of schools. In relation to it, Sugirin et al. (2011) affirms that the steps of planning of methods for teaching strategy are: forming a learning strategy with multicultural materials, analyzing students' characters, making job sheets for students, creating and preparing required learning resources, and doing evaluation and or creating tools or something for evaluation.

McNeil (2010) and Marsh (2014) argue that English teacher can frame and choose some selected cultural materials for teaching English subject based on students' level of competence. Chang (2004), Amy et al. (2007), Cheung and Wong (2002) assert that teachers can establish and develop materials of teaching relating to applicable public stances such as people life, famous local tradition, ethnic group customs, the ceremonial activity of certain people, and thinking ways. Since that, English teachers around the world utilize different methods and various styles of skills to increase students' ability. Richards (2001) and Chang (2004) stated that school's principal and other curriculum developers cannot interfere with the English teacher in choosing the teaching methods, strategies, and approaches. They should instead support the teacher's efforts (Musriadi, 2016); (Badan Standar Nasional Pendidikan, 2006).

In addition, practitioners as such curriculum developers, principals of schools, and English teachers have also not been able to formulate an appropriate curriculum for English subject. They are not able to translate it in accordance with educational objectives to be achieved, such as how to develop teaching materials based on student needs, school environment, local culture of English language teachers and students (Marliah, 2007; Rohmah, 2009). Based on the evidence in the field, the concerns are 
coming from the differences of practitioners' educational background, English teachers' experience, and school environment (Cheung, Wong, 2002; Salahuddin, Khan,, Rahman, 2013; Sugirin et al., 2011; Vallance, 1986).

Thus, department of education and culture of Indonesia determines some implementation principles of English subject curriculum. Practitioners at schools must firstly look at the needs and interests of learners and the environment to be potential for development. Second, they see the learners' diverse and integrated knowledge. Third, they are responsive to developments in science / technology and arts and culture. Fourth, they pay attention its relevance of material development to the students' needs of lives. Fifth, practitioners at schools must think the comprehensive and continuous of English subject curriculum development. Sixth, they promote the importance of lifelong learning, and seventh, the practitioners ought to see the balance between national and regional interests (Badan Standar Nasional Pendidikan, 2006).

\section{Delphi method}

Delphi method is a specifically technique to explore the expected future of novel and evolutionary phenomena of most reliable opinion from experts. According to (Cuhls, 2003), Delphi method is used mainly to assess long-term issues. Custer et al. (1999); Hsu and Sandford (2007), and Linstone and Turoff (2007) argue that Delphi method is available to be used to situations of limited historical data of the hot issue. Adler and Ziglio (1996), Bietau (2011), Keeney et al. (2006), Magnuson (2012); Skulmoski (2007) stated that it is a formalized and traceable method to keep credibility with policy-makers about foresight programs.

This Delphi method selects experts to be participants in the study (Cuhls, 2003). As the procedure, it is aimed at identifying relevant statements or topics for future better amelioration (Keeney et al., 2006; Magnuson, 2012). Common procedure used in Delphi study is using a Delphi list to be assessed by experts for two or three or more rounds, and the final round is used as clarification of their answers (Hsu, Sandford, 2007; Magnuson, 2012) This technique usually uses mean scores and percentage to judge or to sort the unqualified elements. Most researchers using Delphi technique decide to choose the results, which are above thirty percent as a recommendation. Linstone and Turoff (2007) argue that using Delphi technique in conjunction with other methodologies might prove interesting thing because the researcher acquires satisfaction with the accurate data.

\section{Purpose of the study}

The main issues of English subject curriculum are the implementation which is autonomously given to practitioners in schools. The problem of implementing it, however, arises from a various different understanding of practitioners, English teachers, and curriculum developers about the interpretation of the goals, cultural knowledge, values of cultures, and characters to be determined in the curriculum. Therefore, the purpose of this study is an attempt to explore and discuss the implementation of English subject curriculum based on values of cultures and characters in Islamic secondary schools in South Sulawesi province, Indonesia.

\section{Methodology}

This study used survey and interview methods to collect the data. Survey method used 160 items of questionnaire, 80 items of Delphi lists, and both instruments were Likert scale. The questionnaire was distributed to 82 respondents, which consisted of 41 curriculum developers and 41 English teachers taken from Islamic secondary schools in South Sulawesi province, Indonesia. Ten selected experts of curriculum developers and ten selected English teachers were ranked and sorted out from the 82 respondents were used to collect the data through Delphi method. Delphi lists were distributed twice to the twenty selected experts. The first distribution of Delphi lists was to find 
out original response from experts, and the second one was to know the experts' consistency and was used to identify the aspects and elements of "curriculum 2013 character" which should be included in English subject curriculum. Meanwhile, interview was done to 4 selected experts for final clarification.

\section{Findings}

Findings were acquired from data collection using 160 items of a questionnaire about English subject curriculum which were distributed to 82 respondents working in Islamic secondary schools in South Sulawesi province Indonesia. Collected data were analyzed using descriptive statistics to found sum, mean, and standard deviation. 80 items of Delphi lists were used to collect the data from twenty experts for two rounds. Delphi method was used to know experts' views about the implementation of English subject curriculum, which based on curriculum 2013 - character. Data of interview emphasized the findings from Delphi lists.

\section{Curriculum developer's analysis}

The analysis of character's aspects and curriculum components which should be implemented in English subject curriculum. Character's aspects are values, belief, attitudes, and cultures; and curriculum components are goals, contents, methods, and assessments. The result of data analysis estimates widespread of item scoring order. Respondents responded it based on how well it represents their views about characters and curriculum components for teaching English as a foreign language in Islamic secondary schools in South Sulawesi Indonesia. Descriptive statistics of ascending means and descending means were used to make mean, standard deviation, and sum in sequence. Detail results about characters and curriculum components were taken from curriculum developers shown in a table as follows.

Table 1: Sum, mean, and standard deviation of curriculum developers

\begin{tabular}{lllll}
\hline \multicolumn{5}{c}{ Characters } \\
\hline $\mathrm{N}=41$ & Values & Beliefs & Attitudes & Cultures \\
\hline Sum & 84 & 87 & 87 & 90 \\
\hline Mean & 2.048 & 2.121 & 2.121 & 2.195 \\
\hline Std.Dev. & 0.84 & 0.87 & 0.87 & 0.90 \\
\hline \multicolumn{5}{c}{ Curriculum Components } \\
\hline $\mathrm{N}=41$ & Goals & Contents & Methods & Assessment \\
\hline Sum & 87 & 88 & 93 & 85 \\
\hline Mean & 2.121 & 2.146 & 2.268 & 2.073 \\
\hline Std.Dev. & 0.87 & 0.88 & 0.93 & 0.85 \\
\hline
\end{tabular}

\section{English teacher's analysis}

English teachers used the same questionnaire of Likert scale as curriculum developers to find out the characters, which included values, beliefs, attitudes, and cultures, and curriculum components were decided goals, contents, methods, and assessments. The result of data analysis estimates widespread of item scoring order. English teachers responded it based on how well it represents their views about characters and curriculum components for teaching English as a foreign language in Islamic secondary schools in South Sulawesi Indonesia. Descriptive statistics were used to make mean, standard deviation, and sum in sequence. Detail results taken from the English teachers were shown in a table as follows. 
Table 2: Sum, mean, and standard deviation of English teachers

\begin{tabular}{lllll}
\hline \multicolumn{5}{c}{ Characters } \\
\hline $\mathrm{N}=41$ & Values & Beliefs & Attitudes & Cultures \\
\hline Sum & 88 & 89 & 90 & 90 \\
\hline Mean & 2.146 & 2.170 & 2.195 & 2.195 \\
\hline Std.Dev. & 0.88 & 0.89 & 0.90 & 0.90 \\
\hline \multicolumn{5}{c}{ Curriculum Components } \\
\hline Sum & Goals & Contents & Methods & Assessment \\
\hline Mean & 88 & 94 & 93 & 93 \\
\hline Std.Dev. & 2.146 & 2.292 & 2.268 & 2.268 \\
\hline
\end{tabular}

Top ten listed scoring of curriculum developers as well as top ten scoring of English teachers were used to be respondents of Delphi technique. The twenty selected respondents taken from these two groups were given Delphi lists to know the implementation of curriculum 2013 - character. The results of Delphi method were presented as follow.

\section{Results of Delphi method}

Ten items of Delphi lists were used to procure data analysis from the top ten selected curriculum developers and top ten English teachers. Two rounds of Delphi lists were treated to the curriculum developers as well as English teachers. The treatments were done to know the respondents' consistence in responding the integration of character aspects into the themes and topics of English subject.

Curriculum developers. The data analysis shows that the curriculum developers wished to integrate character's aspects into elements of English subject. The highest sum, mean, and standard deviation were expected to cultural aspects. The data in round one showed that all respondents made high responses to values, beliefs, attitudes, and cultures as shown in a table below.

Table 3: Sum, mean, and standard deviation of curriculum developers (round one)

\begin{tabular}{lllll}
\hline \multicolumn{5}{c}{ Integration of characters into elements of English subject } \\
\hline $\mathrm{N}=10$ & Values & Beliefs & Attitudes & Cultures \\
\hline Sum & 38 & 39 & 42 & 45 \\
\hline Mean & 7.60 & 7.80 & 8.40 & 9.00 \\
\hline Std. Deviation & 0.76 & 0.78 & 0.84 & 0.90 \\
\hline
\end{tabular}

There were different improvement of curriculum developers' scores in responding the integration of characters into English subject elements in round two. This positive response to the aspects of characters gained positive pretention to implement English subject curriculum 2013 - character.

Table 4: Sum, mean, and standard deviation of curriculum developers (round two)

\begin{tabular}{l|l|l|l|l}
\hline \multicolumn{5}{c}{ Integration of Characters into Elements of English Subject } \\
\hline $\mathrm{N}=10$ & Values & Beliefs & Attitudes & Cultures \\
\hline Sum & 42 & 46 & 47 & 49 \\
\hline Mean & 2.122 & 2.219 & 2.243 & 2.365 \\
\hline
\end{tabular}




\begin{tabular}{l|l|l|l|l}
\hline Std. Deviation & 0.84 & 0.92 & 0.94 & 0.98 \\
\hline
\end{tabular}

English teachers. The data analysis shows that respondents of English teachers had the same pretentions as curriculum developers to integrate the character's aspects into elements of English subject. The highest sum, mean, and standard deviation were expected to cultural aspects. The data in round one showed that all respondents gave high responses to values, beliefs, attitudes, and cultures as shown in a table below.

Table 5: Sum, mean, and standard deviation of English teachers (round one)

\begin{tabular}{lllll}
\hline \multicolumn{5}{c}{ Integration of characters into elements of English subject } \\
\hline $\mathrm{N}=10$ & Values & Beliefs & Attitudes & Cultures \\
\hline Sum & 41 & 42 & 43 & 45 \\
\hline Mean & 8.20 & 8.40 & 8.60 & 9.00 \\
\hline Std. Deviation & 0.82 & 0.84 & 0.86 & 0.90 \\
\hline
\end{tabular}

The top ten English teachers made improved scores in responding the integration of characters into English subject elements in round two. This positive response to the aspects of characters gave beyond expectations to implement English subject curriculum 2013 - character.

Table 6: Sum, mean, and standard deviation of English teachers (round two)

\begin{tabular}{lllll}
\hline \multicolumn{5}{c}{ Integration of characters into elements of English subject } \\
\hline $\mathrm{N}=10$ & Values & Beliefs & Attitudes & Cultures \\
\hline Sum & 45 & 46 & 45 & 48 \\
\hline Mean & 9.00 & 9.20 & 9.00 & 9.60 \\
\hline Std. Deviation & 0.90 & 0.92 & 0.90 & 0.96 \\
\hline
\end{tabular}

\section{Interview}

Results of interview were adopted from four experts of curriculum developers and four others from experts of English teachers. These eight interviewees were selected from the whole of 82 respondents used in this study. Main topics of interviewing question were focused on contents character aspects to be integrated in teaching elements of English language.

Interview Question - Do you think the integration of character aspects into the elements of English subject can be implemented? If Yes, why? Or No, why?

Four experts of curriculum developers and four English teachers resulted comments which reflect the understandings of most.

Curriculum developers. One out of the four experts of curriculum developers expressed about the integration of character aspects. Findings show the character aspects which may be integrated namely values, beliefs, attitude, and cultures. Interviewee 1 did not suggest it clearly about the strategy to implement the character aspects in English subject curriculum as follow.

The first interviewee $(11, F, 23)$ stated that:"... the values, beliefs, attitudes, and cultures must be integrated in teaching and learning process to improve students' knowledge ... and ... cross-cultures through English subject. Students need to know other cultures ... to increase their understanding to the differences. ... Learning English by character aspects will be more interesting at school..." 
While, interviewee 2 strongly endorsed to integrate selected aspects of characters. This curriculum developer expected professional teachers take action in selecting appropriate characters to be included in curriculum for teaching English subject as presented as follow.

The second interviewee (No.05, F, 37) said: “... certain aspects of characters can be integrated into English knowledge and English skills. However,... professional teacher needs ... to select appropriate contents of values, beliefs, attitudes, and ... cultures to be implemented in teaching English as a foreign language. Teachers should be able to ... understand the school environment..."

The response of interviewee 3 strongly agrees with the integration of character aspects and must be employed by acknowledgeable and experienced teachers.

The third interviewee (No.17, M, 22) said: “... all aspects of characters can be integrated ... into elements of English subject ... but the teacher needs to be trained ... how to integrate...how to make and use the teaching programs, what teaching methods should be used, etc.,..."

The interviewee 4 of expert of curriculum developers suggested to English teachers to select and screen relevant aspects of characters to be implemented which based on environmental condition.

The fourth interviewee (No. 20, F, 06) argued: “... English teachers may implement some suitable and relevant aspects of character based on student's need, school environment, teacher's ability, and supporting facility..."

Overall findings from the 4 experts of curriculum developers have similar views about the area of knowledge coming from them. They strongly agree with the implementation of integration the characters in elements of English subject. Selected and relevant national and local cultural materials were recommended to English teachers to include them in teaching program for TEFL. It was believed that all teaching materials regarding with characters (cultures, beliefs, and values) were very necessary for students.

\section{English teachers}

In this section of English teacher's interview, researcher used one the same question as for experts of curriculum developers concerning with the integration of character aspects into the elements of English subject. The responses of the first interviewee of expert of English teachers expressed as follow.

The first interviewee $(02, F, 61)$ argued:"... we can integrate and implement the values, beliefs, attitudes, and cultures in teaching and learning process. ... We also need guidance from government and advisors. Most English teachers enjoyed using curriculum which integrates the characters... students feel interesting to study English skills when cultures and other aspects of characters be used..."

The second interviewee $($ No.12, F, 49) said “... groups of teachers learnt how to integrate certain aspects of characters into English knowledge and ... English skills. As teacher, we need to select appropriate contents of values, beliefs, attitudes, and cultures to be implemented in teaching English subject at school. We shared about the school environment and character of students..." 
The third interviewee (No.29, M, 78) said that “... teachers tried to integrate all aspects of characters into elements of English subject ... but some teachers still need to be trained and guided by supervisors how to integrate ... how to make and use the teaching programs, what teaching methods which should be used, etc.,..."

The fourth interviewee (No. 14, M, 60) argued that “... English teachers can implement certain appropriate aspects of character based on the student's need, school environment, teacher's ability, and supporting facility..."

\section{Discussion and conclusion}

The use of current English subject curriculum which include characters in each elements of English language becomes a hot issue in Indonesia. The results of this study describe that the respondents strongly agree with the implementation of "curriculum 2013 - character", however, the curriculum developers and English teachers need to learn the strategy to integrate aspects of character into elements of English through the understanding of curriculum goals, contents, teaching methods, and assessments.

It was found that selection of curriculum content and teaching activities for every elements of English subject should be based on the learning objectives, cultural life, and orientation which have positive values for student's beliefs". This section was included in technology aspect of curriculum orientation inventory together with the data of self-actualization aspect of curriculum orientation inventory, which discussed about "increasing students' sense of personal meaning and sense of direction in life is major purpose of schooling". The results, in general, showed that the standard deviation of integration characters and the use of curriculum components were smaller than the value of alpha 0.05 (see table 1 and table 2).

Delphi method findings showed that all experts agreed very much to integrate the aspects of characters (values, beliefs, attitudes, and cultures) into elements of English subject such as knowledge aspects: vocabulary, grammar, spelling, and English skills such as writing, reading, speaking, and listening skills. The sum, mean scores, and standards deviation gained from both experts of curriculum developers and English teachers indicated positive responses and showed the increase of sum from round one to round two at each aspects of characters and elements of English (see table 3, 4, 5, and 6). However, the experts suggested to school, government, and advisor to guide them how to integrate the whole aspects of characters into elements of English subject, which should be suited with the school environment, and level of students.

Most experts said that teachers got difficult to do assessment of characters in detail because they do not have enough time and facility to form the model of individual assessment as recommended by curriculum 2013 - character. Teachers could assess students' characters individually if its number is not too large.

Findings through interview strongly supported the data obtained through questionnaire and two rounds of Delphi lists use. All interviewees had the same opinion about the implementation of English subject curriculum in Islamic secondary schools in Indonesia, particularly in South Sulawesi province. The interviewees thought that they strongly supported to implement curriculum 2013 - character.

\section{Bibliographic references}

ADLER, M. - ZIGLIO, E. 1996. Gazing Into the Oracle: The Delphi Method and Its Application to Social Policy and Public Health. Jessica Kingsley Publishers. ISBN 9781853021046.

AMY, S. H. - KEH, N. C. - XU, B. 2007. A comparative study on value orientations of physical education teachers among Hong Kong, Taiwan, and Shanghai. 
International Journal of Eastern Sports and Physical Education, vol. 5, n. 1, pp. 141151. ISSN 2092-8211.

BADAN STANDAR NASIONAL PENDIDIKAN. 2006. Panduan Penyusunan Kurikulum Tingkat Satuan Pendidikan Jenjang Pendidikan Dasar dan Menengah. Jakarta Indonesia: Badan Standar Nasional Pendidikan.

BIETAU, L. A. 2011. Measuring civic knowledge: using the Delphi method to construct a civic knowledge inventory for elementary teachers (Doctoral dissertation, Kansas State University).

CHANG, W. 2004. A Cross-Cultural Case Study of a Multinational Training Program in the United States and Taiwan. Adult Education Quarterly, vol. 54, n. 3, pp. 174192. ISSN 1552-3047.

CHEUNG, D. - WONG, H. 2002. Measuring Teacher Beliefs about Alternative Curriculum Designs. The Curriculum Journal, vol. 13, n. 2, pp. 225-248. ISSN 14693704.

CUHLS, K. 2003. From forecasting to foresight processes-new participative foresight activities in Germany. Journal of forecasting, vol. 22, n. 2 - 3, pp. 93-111. ISSN 1099-131.

CUSTER, R. L. - SCARCELlA, J. A. - STEWART, B. R. 1999. The Modified Delphi Technique - A Rotational Modification. Journal of Vocational and Technical Education, vol. 15, n. 2. ISSN 1533-1830.

DEDE, R. 2005. Paradigma Pendidikan Demokratis: Sebuah Model Pelibatan Masyarakat dalam Penyelenggaraan Pendidikan. Jakarta: Prenada Media. ISBN 9789793464060.

DEPARTEMEN PENDIDIKAN NASIONAL. REGULATION MINISTER OF NATIONAL EDUCATION OF THE REPUBLIC OF INDONESIA, NUMBER 16, 2007. 2007. Jakarta: Depdiknas RI.

GLATTHORN, A. A. 2004. Developing a Quality Curriculum. Waveland Press. ISBN 978-1577663409.

HASBULLAH, S. - SIDIN, Z. B. H. 2014. Integrating Cross Cultural Curriculum into School Based Curriculum: Using Peer Review Technique to Enhance Learners' English Vocabulary. Sains Humanika, vol. 2, n. 4, pp. 79-83. ISSN 2289-6996.

HLEBOWITSH, P. S. 2005. Designing the School Curriculum. Virginia, USA: Pearson/Allyn and Bacon. ISBN 978-0205391394.

HSU, C.-C. - SANDFORD, B. A. 2007. The Delphi Technique: Making Sense of Consensus. Practical Assessment, Research \& Evaluation, vol. 12, n. 10, pp. 1-8. ISSN 1531-7714.

INTANSARI, R. 2013. Teachers' Strategy in Implementing English Curriculum in a Junior High School in Indonesia. Indonesian Journal of Applied Linguistics, vol. 2, n. 2, pp. 226-235. ISSN 2502-6747.

KEENEY, S. - HASSON, F. - MCKENNA, H. 2006. Consulting the Oracle: Ten Lessons from Using the DELPHI Technique in Nursing Research. Journal of Advanced Nursing, vol. 53, n. 2, pp. 205-212. ISSN 1365-2648.

KEMENDIKBUD. 2012. Dokumen Kurikulum 2013. Kementerian Pendidikan dan Kebudayaan.

KLEIN, T. - MCLEOD, S.H. 1990. Strengthening Programs for Writing across the Curriculum. College Composition and Communication, vol. 41, n. 1, pp. 97-98. ISSN 1939-9006.

LEE ODELL, W. 2001. Element of Language: Fourth Course. Holt Rinehart and Winston. ISBN 978-0030686887.

LINSTONE, H. A. - TUROFF, M. 2007. The Delphi Method: Techniques and Applications. Addison-Wesley Pub. Co., Advanced Book Program, 1975. ISBN 9780201042948.

LONIGAN, C. J. - FARVER, J. M. - PHILLIPS, B. M. - CLANCY-MENCHETTI,

J. 2011. Promoting the Development of Preschool Children's Emergent Literacy 
Skills: a Randomized Evaluation of a Literacy-focused Curriculum and Two Professional Development Models. Reading and Writing, vol. 24, n. 3, pp. 305-337. ISSN 1573-0905.

MAGNUSON, L. A. 2012. A Delphi study to understand relational bonds in supervision and their effect on rehabilitation counselor disclosure in the public rehabilitation program.

MARLIAH, L. 2007. Efficient Reading. Sosioteknologi, vol. 6, n. 11, pp. 267-272. ISSN 1858-3474.

MARSH, C. J. 2014. Perspectives: Key Concepts for Understanding the Curriculum. Routledge. ISBN 9780750705875.

MCNEIL, J. D. 2010. Curriculum: the Teacher's Initiative. Merrill, 1995. ISBN 9780130938046.

MUSRIADI. 2016. Profesi Kependidikan Secara Teoretis dan Aplikatif: Panduan Praktis bagi Pendidik dan Calon Pendidik. Jakarta: Deepublish. ISBN 9786024752675.

MYLES, B. S. - TRAUTMAN, M. L. - Schelvan, R. L. 2004. The Hidden Curriculum: Practical Solutions for Understanding Unstated Rules in Social Situations. Autism Asperger Publishing Company.

O'BANNON, B. - JUDGE, S. 2004. Implementing Partnerships across the Curriculum with Technology. Journal of Research on Technology in Education, 37(2), 197-216. https://doi.org/10.1080/15391523.2004.10782433.

RICHARDS, J. C. 2001. Curriculum Development in Language Teaching. Cambridge University Press. ISBN 9780521804912.

RICHARDS, J. C. 2005. Curriculum Development in Language Teaching. Cambridge: Cambridge University Press. ISBN 9780511667220.

ROHMAH, Z. 2009. EFL Materials in Madrasah Tsanawiyah: What do they really Need? TEFLIN, vol. 20, n. 1, pp. 104-117. ISSN 2356-2641.

SALAHUDDIN, A. N. M. - KHAN, M. M. R. - RAHMAN, M. A. 2013. Challenges of Implementing English Curriculum at Rural Primary Schools of Bangladesh. The International Journal of Social Sciences, vol. 7, n. 1, pp. 34-51. ISSN 2305-4557.

SANJAYA, W. 2012. Kurikulum dan Pembelajaran Kompetensi. (R. Novitasari, Ed.). Bandung: Kencana. ISBN 9786028650809.

SILVA, T. - BRICE, C. 2004. Research in Teaching Writing. Annual Review of Applied Linguistics, vol. 24, pp. 70-106. ISSN 1471-6356.

SKULMOSKI, G. J. - HARTMAN, F. T. - KRAHN, J. 2007. The Delphi Method for Graduate Research. Journal of Information Technology Education, vol. 6, pp. 1-21. ISSN 1547-9714.

SUDIN, A. 2014. Kurikulum dan Pembelajaran. Jakarta: UPI Press. ISBN 9789793786377.

SUGIRIN, SUDARTINI, S. - SUCIATI - NURHAYATI, L. 2011. A Study on Cultural Integration in the English Textbooks for Junior High Schools. Litera, vol. 10, n. 2, pp. 235-246. ISSN 2460-8319.

SUKMADINATA, N. S. 1997. Pengembangan Kurikulum: Teori dan Praktik. PT Remaja Rosdakarya. ISBN 9789795146018.

SUSANTO. 2007. Pengembangan KTSP dengan Perspektif Manajemen Visi. Matapena. ISBN 1559639601.

SUWARNO, R. 2011. Aligning Instructional Practices with Content Standards in Junior Secondary Schools in Indonesia. Brigham Young University.

TIM PENELITI DEPDIKNAS. 2007. Model Silabus dan Rencana Pelaksanaan Pembelajaran. Jakarta: Badan Penelitian dan Pengembangan Departemen Pendidikan Nasional.

VALLANCE, E. 1986. A Second Look at Conflicting Conceptions of Curriculum. Theory into Practice, vol. 25, n. 1, pp. 24-30. ISSN 1543-0421.

XLinguae, Volume 12, Issue 4, October 2019, ISSN 1337-8384, eISSN 2453-711X 
YAUMI, M. 2013a. Pembelajaran Berbasis Kecerdasan Jamak (Multiple Intelligences): Mengidentifikasi dan Mengembangkan Multitalenta Anak. Jakarta: Kencana. ISBN 978-6027985490.

YAUMI, M. 2013b. Prinsip-Prinsip Desain Pembelajaran (First Edit). Jakarta.

Prenada Media Group. ISBN 9786021186121.

Words: 5112

Characters: 34929 (19,41 standard pages)

Dr. Muhammad, M.Pd., MS

Universitas Islam Negeri (UIN) Mataram,

Indonesia

muhammad@uinmataram.ac.id

Hasbullah, M.Pd., PhD.

Sekolah Tinggi Agama Islam Negeri (STAIN) Sorong, Papua Barat,

Indonesia

hasbullahsaid68@gmail.com

Dr. Syarifudin, M.Pd.

Universitas Islam Negeri (UIN) Mataram,

Indonesia

syarif@uinmataram.ac.id

Andi Anto Patak, Ph.D

English Department, Faculty of Languages and Literature, Universitas

Negeri Makassar

Jl. Mallengkeri, Parangtambung Campus, Makassar, South Sulawesi, 90224,

Indonesia

andiantopatak@unm.ac.id 